\title{
Human Intraepithelial Lymphocytes
}

\author{
Allan McI. Mowat \\ Department of Bacteriology and Immunology, Western Infirmary, Glasgow G11 6NT, UK
}

\section{Introduction}

Intraepithelial lymphocytes (IEL) are one of the largest populations of lymphocytes in the body and by virtue of their position have the closest direct relationship with foreign antigens (Fig. 1). These include many potentially pathogenic organisms, as well as a wide variety of other non-replicating antigens such as food proteins and other immunogenic materials. These features predict that IEL have an important role in protecting the intestinal mucosa against invading antigens. Furthermore, an increased proportion of IEL is a characteristic feature of the pathology of many small intestinal disorders, suggesting that these lymphocytes may also be involved in producing enteropathy.

Despite the apparent importance of IEL in vivo, surprisingly little of their nature and function has been determined with certainty. This is particularly true of human IEL, where difficulties are increased by the limited availability of tissue samples of appropriate size and origin. Furthermore, many studies of isolated "IEL" in man have used populations of "mucosal lymphocytes", rather than wellcharacterised preparations of pure IEL and are, thus, impossible to interpret. In this review, I shall describe the features and possible biological functions of IEL, with particular reference to their roles in health and disease. Although I shall concentrate on IEL from human small intestine, where appropriate I shall refer to studies using animal IEL. Finally, as many features of human IEL have been reviewed in the fairly recent past $[28,31]$, I shall emphasise more recent findings on the phenotype and functions of these cells.

\section{General Features of IEL}

\section{Location and Occurrence}

Intraepithelial lymphocytes were first described in the mid 19th century [115] and have since been found in most vertebrate species which have been examined. In man and laboratory rodents, IEL are distributed widely and relatively evenly 


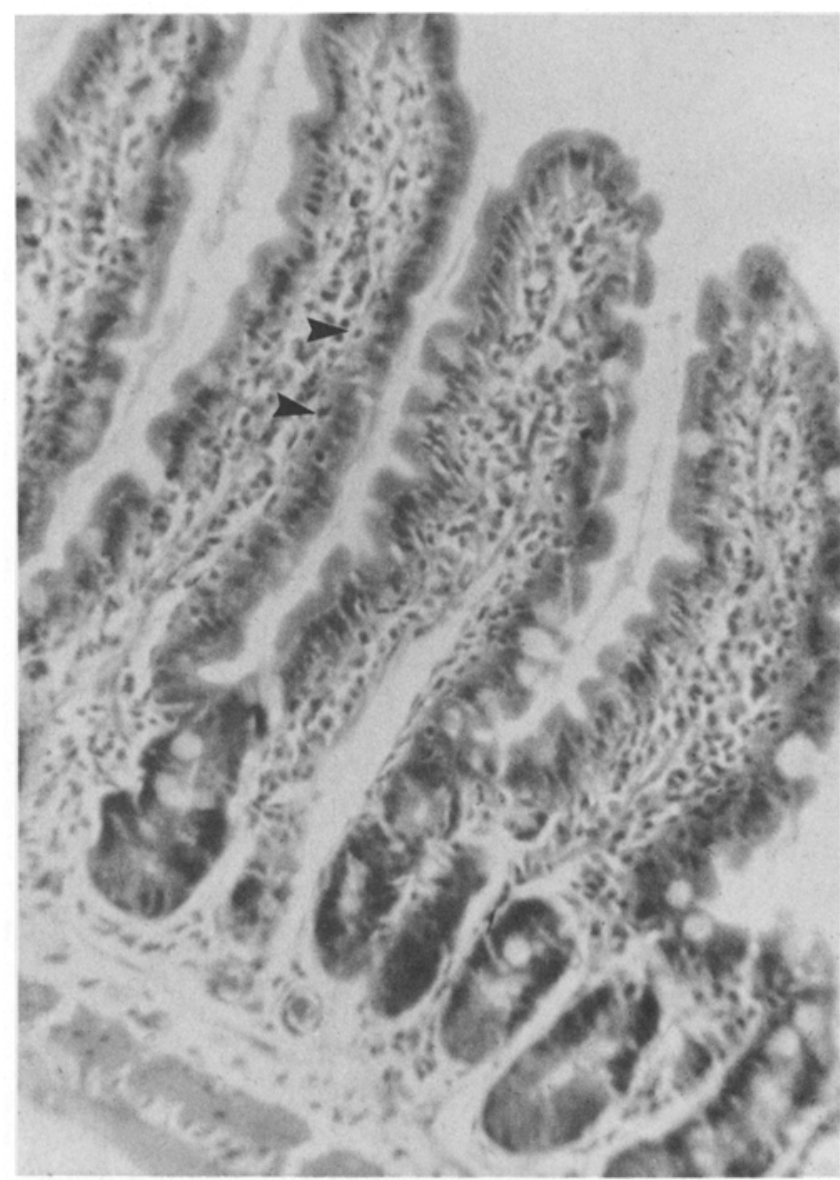

Fig. 1. Distribution of intraepithelial lymphocytes (IEL) in the normal human jejunum. IEL (arrowed) are positioned on the basement membrane at all levels of the villus. $\mathrm{H}+\mathrm{E}, \times 350$

throughout the small intestine. Large numbers of epithelial lymphocytes also occur in the stomach, colon and rectum, although there may be less IEL in more distal parts of the gut [28]. Similar cells have been described in other epithelial tissues, including bronchus, breast and the urogenital tract. Most of these populations of IEL have not been studied in any detail and their relationship to small bowel IEL is unknown. However, as I shall describe, evidence is accumulating that epithelial lymphocytes may form a discrete compartment of the immune system.

Approximately $15 \%-20 \%$ of cells in the normal small intestinal epithelium are lymphocytes (Fig. 1), with 40 IEL/100 epithelial cells being the arbitrary upper limit of normal in human gut $[30,31]$. Virtually all IEL lie on the basement membrane (BM) between the enterocytes and are never found within epithelial cells (Fig. 2), although in disease states, IEL may be found closer to the luminal surface of the epithelium [30]. There are no desmesomes or tight junctions between IEL and surrounding enterocytes and cytoplasmic extrusions from IEL can often be 
seen pushing their way through the intercellular space between adjacent epithelial cells [77]. It has been suggested that rarely an entire IEL may move into the lumen and attach to potentially invasive organisms [93], but this concept is difficult to prove directly.

IEL are found throughout the height of the epithelium from near the crypt base to the villus tip. Nevertheless, there are generally fewer IEL in the crypts or in the distal parts of the villus and the highest density seems to occur in association with the mature enterocyte compartment of the mid-villus region. We have also noted an unusually high frequency of IEL in proximity to goblet cell nuclei (unpublished observations), but the significance of this finding is unclear.

\section{Morphology}

The morphological features of IEL have been somewhat controversial and may show some species variation. Nevertheless, there now seems to be general agreement that a substantial proportion of human IEL, even from normal intestine, are larger than lymphocytes from other tissues. Around three-quarters are described as medium-sized and have some features consistent with activation, including prominent lysosomes and a large amount of nuclear heterochromatin $[9,11,36,66$, $92,113]$. True lymphoblasts are rare, but the possibility that many IEL are activated is supported by their "amoeboid" appearance in situ $[113,118]$ and by their unusually high locomotor activity in vitro (see below).

A further characteristic feature of IEL from all species is the presence of two to three, or more, small azurophilic cytoplasmic granules (Fig. 2). In man, around $25 \%$ of IEL contain granules, but this may often be higher and can approach $80 \%$, particularly in rodent studies $[9,11,15,18,36,38,76,112]$. The nature of these granules has not been determined with certainty and has provoked considerable speculation over the origin and lineage of IEL. Apparently lysosomal in nature, the granules stain metachromatically with Astra blue or toluidine blue at low $\mathrm{pH}$, contain sulphur-containing glycosaminoglycans $[38,41,95]$ and appear to be associated with serine esterase activity [41]. Although these features initially suggested that IEL were part of the unusual population of mast cells found in the intestinal mucosa [38], there is now considerable evidence that IEL and mucosal mast cells (MMC) are distinct [41, 95, 101]. Furthermore, MMC precursors are rare among IEL [101].

Granulated IEL also share many of the morphological features associated with the large granular lymphocytes (LGL) which are responsible for natural killer (NK) cell activity in other tissues. Other evidence does not support the view that a large proportion of IEL are NK cells (see below), but similar granules occur in many different populations of activated $\mathrm{T}$ lymphocytes, particularly those with cytolytic function [37].

\section{Origin and Ontogeny of IEL}

\section{Origin and Fate}

The early hypothesis that IEL were a closed compartment of self-renewing lymphocytes [33] is untenable in face of the fact that few IEL synthesise DNA in 

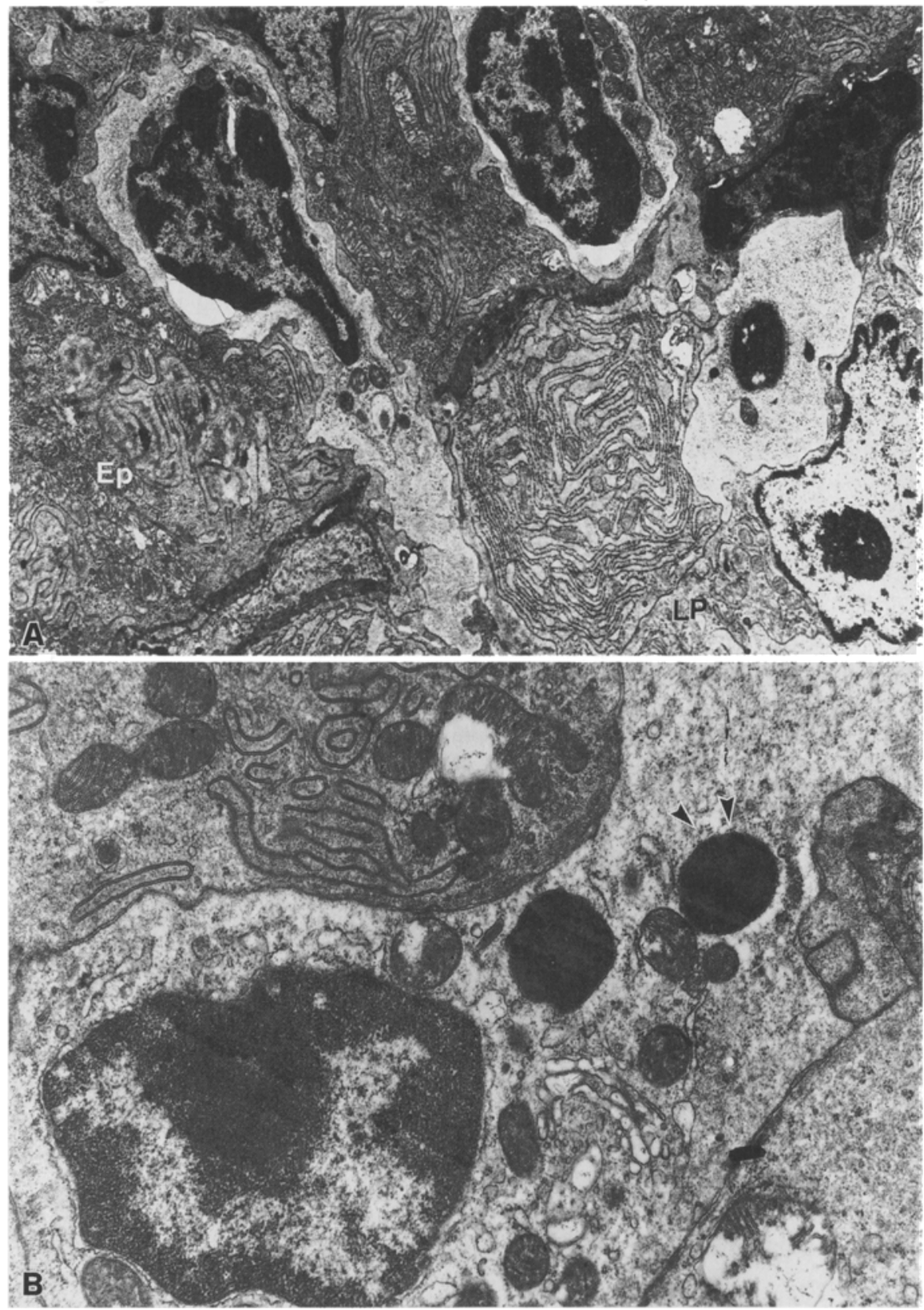

Fig. 2A, B. Electron microscopic appearance of IEL. A An IEL crossing the basement membrane into the epithelium ( $E p)$ from the lamina propria $(L P)$. B Characteristic lysosomal granules in the cytoplasm of the IEL (arrowed). A $\times 11,200$, B $\times 29,400$ 
situ. There is an extremely low number of mitotic figures among normal human IEL $(1 / 30,000 \mathrm{IEL} ;[68,69])$, while kinetic studies in mice have suggested a baseline turnover rate of $<1 \%$ for IEL, but with almost complete replacement of the population every $3-4$ days $[38,60,67,98]$. From these studies, it has been calculated that IEL derive from a rapidly dividing pool of precursors most of which have divided within 2-3 days. Interestingly, many IEL are themselves radioresistant and their precursors recover quickly from radiation [26].

The source of IEL precursors and their routes of migration to the epithelium have not yet been proven conclusively. Animal studies show that Peyer's patches are necessary for the normal reconstitution of IEL populations [38], while radiolabelled $\mathrm{T}$ lymphoblasts from mesenteric lymph nodes (MLN) and thoracic duct lymph (TDL) may localise in the epithelium after recirculating through blood $[78,108]$. This pathway is similar to that described for the recruitment of IgAcommitted B lymphocytes into the intestinal lamina propria (LP) and would suggest that IEL derive from antigen-reactive precursors in the Peyer's patches (Fig. 3). Whatever the original source of IEL, clearly these cells must ultimately traverse the LP before entering the epithelium. This is shown clearly in electron microscopy (EM) studies which observe IEL breaking through the BM into the epithelial layer (Fig. 2). Furthermore, recent elegant studies of immunologically induced enteropathy in human gut in vitro have shown that activation of LP lymphocytes is paralleled by reconstitution of IEL numbers [79]. These findings make the fact that IEL and LP lymphocytes comprise very different populations all the more surprising (see below).

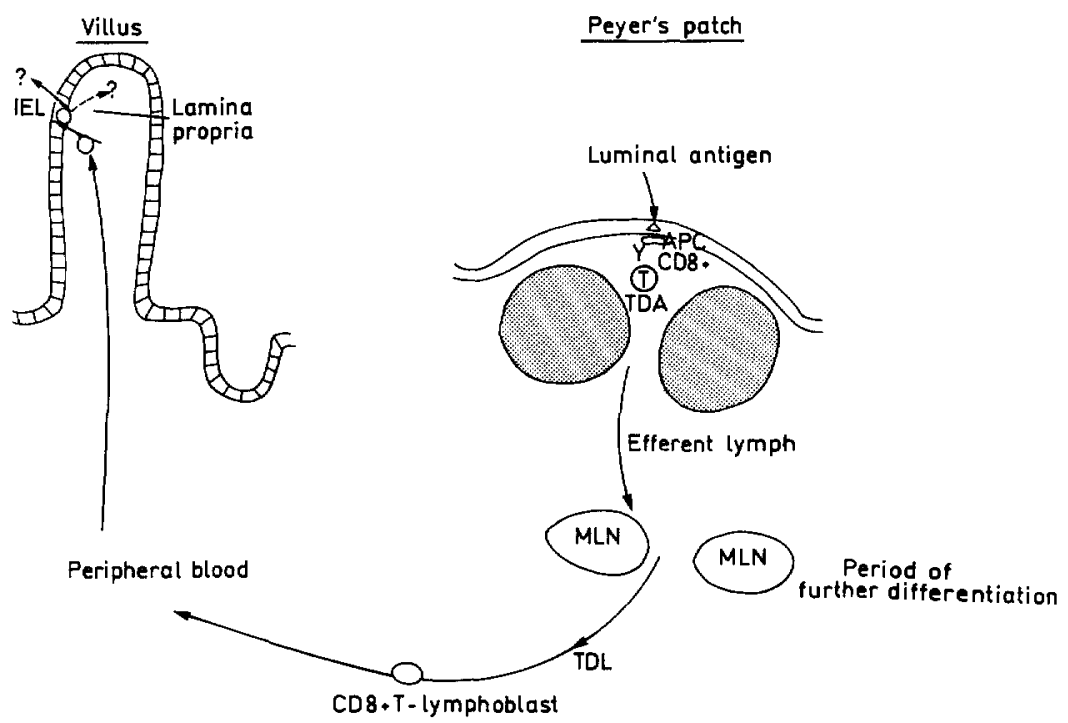

Fig. 3. Probable recirculation pathways of IEL precursors which first encounter antigen in the Peyer's patch and migrate to the mucosa via the thoracic duct and arterial blood after a period of differentiation in the mesenteric lymph node 
The fate of IEL is unclear and remains controversial. As noted above, most IEL have a short life-span within the epithelium, although some may remain for much longer periods $[67,98]$. That IEL are merely lost into the lumen, possibly by migrating up the villus with the enterocyte sheet has never been shown directly and is probably inconsistent with the predominantly basal position of IEL within the epithelium. Furthermore, even IEL near the enterocyte extrusion zone at the villus tip show none of the signs of degeneration which might be expected in an effete population $[22,70]$. Thus, it seems more likely that IEL leave the epithelium by re-entering the LP, an idea which is supported by EM studies appearing to show IEL breaking the BM in the direction of the LP [113]. The ultimate fate of IEL after leaving the epithelium is entirely unknown. Despite initial evidence to the contrary [38], detailed studies in mice show that isolated IEL have no capacity to return to the mucosa by recirculating through blood and lymphoid tissues [2]. Therefore, it must be assumed that IEL either die in the LP or use less conventional routes of migration to re-enter lymphoid tissues. Intriguing, but uncorfirmed, observations in chickens suggest that parasite-infected IEL may indeed return to the peripheral immune system, perhaps supporting the view that IEL continue to function for some time after leaving the epithelium [57].

\section{Ontogeny and Factors Influencing IEL Populations}

Lymphocytes are virtually absent from the epithelium of newborn rodents and increase only slowly towards adult levels thereafter [28, 63, 85]. However, in man, IEL appear in foetal life soon after other lymphoid organs such as the thymus have developed at around 11 weeks of gestation [105]. Thereafter, the number of IEL increases gradually through pregnancy, although adult levels are probably not achieved until some time after birth. In both man and rodents, the predominance of granulated and $\mathrm{CD}^{+}$lymphocytes appears early in the ontogeny of IEL [63, 105].

These findings indicate that IEL can develop early in life and in the absence of a normal intestinal environment. Nevertheless, it should be emphasised that, compared with adult levels, IEL numbers remain very low in the neonate and only begin to increase rapidly during the weaning period [28, 63, 85]. Very low numbers of IEL are found under germ-free conditions $[8,28,97]$ and a depressed IEL count has even been reported in normal individuals placed on a milk-free diet [96]. As IEL and their precursors exhibit normal turnover kinetics in germ-free rodents [98], and IEL precursors migrate normally into germ-free intestine [28], the low numbers of IEL seems to reflect a lack of local factors which normally retain recirculating lymphocytes in the gut wall. Whether this reflects effects of specific antigens or other, non-specific products of, e. g. luminal bacteria, remains to be determined.

Most studies show that congenital or acquired absence of the thymus leads to very low numbers of IEL in rodents, chickens and man [28]. Nevertheless, the status of IEL in athymic animals is somewhat controversial, with some reports that there may be a significant population of thymus-independent, granulated IEL in rats and man $[75,76]$. The immunological significance of these findings will be discussed below. 


\section{Immunological Features of IEL}

The morphological and developmental studies described in preceding sections emphasise that IEL are not only a highly unusual compartment of the immune system, but that there may also be heterogeneity within this population. These concepts are reinforced and extended by the immunological investigations which have been performed on IEL.

\section{Phenotypic Features}

T Lymphocyte Markers on IEL. As noted earlier, there is considerable evidence that many, if not virtually all, IEL are thymus-dependent lymphocytes. This is supported by the uniform findings that IEL from all species contain virtually no $\mathrm{sIg}^{+}$B lymphocytes and by the absence of macrophages [22]. Furthermore, initial studies using human $\mathrm{T}$ lymphocyte-specific monoclonal antibodies showed that 95\% or more IEL carried the CD3 marker which is associated with the $\mathrm{T}$ cell receptor $(\mathrm{TcR})$ on all $\mathrm{T}$ cells $[102,103]$. This finding has since been amply confirmed by many other workers $[9,13,36,45,46,65,107]$. The lack, until recently, of equivalent CD3-specific reagents has prevented similar studies in other species, but it has been reported that $85 \%-90 \%$ of mouse IEL are $\mathrm{CD}^{+}$[35]. Interestingly,in our own work, we have found that mouse IEL seem to express less CD3 than conventional T lymphocytes (I. N. Crispe \& A. McI. Mowat, unpublished observations). Many of the other phenotypic features of IEL also distinguish them from conventional populations of $T$ lymphocytes (Table 1). Although most IEL express some markers which are found as pan $\mathrm{T}$ cell antigens on other $\mathrm{T}$ cells, including CD2 $[11,13,23,36]$, other pan $T$ cell markers are absent from a significant proportion of IEL including CD5 $[7,13,46,65,103]$, Thy- 1 in mice [19, $20,26,51,94]$ and $\mathrm{W} 3 / 13$ in rats [61]. In mice, IEL also do not carry the MEL 14 antigen found on mature recirculating $T$ cells [58].

The most remarkable phenotypic characteristic of IEL is the large predominance of $\mathrm{CD} 8{ }^{+} \mathrm{T}$ lymphocytes (Fig. 4). Whereas $\mathrm{T}$ lymphocytes from peripheral blood and most other lymphoid tissues have a $\mathrm{CD}^{+}: \mathrm{CD} 8^{+}$ratio of around $2: 1$,

Table 1. Expression of lymphocyte markers by human intraepithelial lymphocytes (IEL)

\begin{tabular}{lc}
\hline Phenotypic marker & Proportion of IEL positive \\
\hline CD3,CD2 & $>90 \%$ \\
CD4 & $5-10 \%$ \\
CD8 & $75-85 \%$ \\
CD3 ${ }^{+}$CD4 ${ }^{-}$CD8 - & $5 \%$ \\
& \\
CD5 & $30 \%$ CD8 ${ }^{+}$IEL \\
& $90 \%$ CD4 ${ }^{+}$IEL \\
CD25 (IL 2 receptor) & $0 \%$ \\
HNK-1, CD16, Leu11b & $1-2 \%$ \\
MHC class II & $<1 \%$ \\
\hline
\end{tabular}


$75 \%-85 \%$ of $\mathrm{CD}^{+}{ }^{+}$IEL are $\mathrm{CD} 8^{+}$and $<10 \%$ are CD4 ${ }^{+}$(Table $1 ;[9,11,13$, $19,20,23,26,35,36,45,46,51,58,61,65,102,103,107])$. More significantly, $\mathrm{T}$ lymphocytes from the adjacent LP are completely unlike IEL and have similar expression of CD4/CD8 to that of peripheral blood lymphocytes (PBL) $[102,103]$. This large population of CD8 ${ }^{+}$IEL accounts for most of the aberrant expression of other, pan T cell markers, with up to $70 \%$ of human $\mathrm{CD} 8^{+}$IEL being CD5 ${ }^{-}$ $[13,65,103]$ and around $50 \%$ of murine IEL are CD8 ${ }^{+}$Thy $^{-}{ }^{-}[9,20,26,51$, 94]. In contrast, $\mathrm{CD} 4^{+}$IEL seem to express other $\mathrm{T}$ cell markers (normally) although some workers have reported a small proportion of $\mathrm{CD}^{+} \mathrm{CD}^{-}$cells [9]. Although $\mathrm{CD} 8^{+} \mathrm{T}$ cells from other tissues do not usually share this defective expression of pan T cell markers, some CD8 ${ }^{+}$LP lymphocytes do show similar features $[65,103]$, while $\mathrm{CD} 8^{+} \mathrm{CD}^{-} \mathrm{T}$ cells have been described in the skin of patients with graft-versus-host $(\mathrm{GvH})$ disease [44] and in rejecting renal allografts [6]. Interestingly, athymic mice have $\mathrm{CD} 8^{+}$but no $\mathrm{CD} 4^{+} \mathrm{IEL}$, suggesting that at least some CD ${ }^{+}$IEL may be thymus independent $[52,54,59]$. Nevertheless, the low number of IEL in such animals indicates that this population is likely to be small under normal conditions.

Expression of TCR by IEL. Recent studies have suggested that the unusual phenotype of IEL may reflect the presence of a discrete population of T cells with a distinct developmental lineage. Thus, it has been reported that murine and chicken $\mathrm{CD}^{+}$IEL express the $\gamma \delta$ form of the TcR for antigen, which is rarely found on mature $\mathrm{T}$ lymphocytes and is normally restricted to developing thymocytes $[4,7,35]$. Interestingly, T cells in skin epidermis also use the $\gamma \delta \mathrm{TcR}[109]$

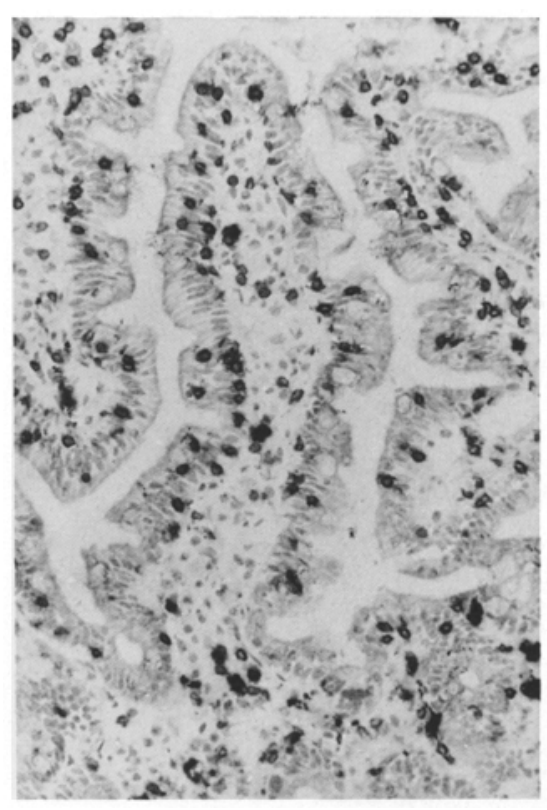

Fig. 4. Distribution of $T$ lymphocytes in epithelium of human jejunum. Virtually all IEL are $\mathrm{CD}^{+}$, while the lamina propria contains many non $T$ cells. Immunoperoxidase, $\times 245$ (reproduced by kind permission of Dr. J. Spencer) 
and these findings have led to the hypothesis that $\gamma \delta^{+}$IEL are part of a primitive population of effector $T$ cells whose function is to protect the superficial layers of the body, including the skin, gut and respiratory tract $[43,109]$. However, it should be noted that murine IEL express a family of $\gamma \delta$ receptors which is different to that employed by either thymic or skin $\gamma^{+}$T cells [4], suggesting that IEL may be a unique family of $T$ cells. It is important to emphasise that most of these immunochemical studies have yet to be confirmed and they contrast with phenotypic work on IEL. Thus, $5 \%$ of less of human IEL have the $\mathrm{CD}^{+}$ CD4 ${ }^{-} \mathrm{CD}^{-}$phenotype normally associated with $\gamma \delta^{+} \mathrm{T}$ cells in other sites (Fig. 4 ; $[13,45,46,107])$ and $>90 \%$ of human CD3 ${ }^{+}$IEL carry the WT31 marker which characterises mature T cells with the conventional $\alpha \beta \mathrm{TcR}$ [13]. Furthermore, we have found that the proportion of murine IEL (including CD8 ${ }^{+}$ IEL) which express the $V_{\beta} 8$ and $V_{\beta} 6$ families of $\alpha \beta$ TcR is almost the same as that in other $\mathrm{T}$ cell populations. Together, these findings do not support the view that most IEL are $\gamma^{+}$T cells. Nevertheless, a small $(<10 \%)$ proportion of human IEL are $\mathrm{CD} 3{ }^{+} \mathrm{CD}^{-}{ }^{-} \mathrm{CD} 8{ }^{-} \mathrm{T}$ cells and a similar number have been reported to be WT $31^{-}$and to express the $\gamma \delta$ receptor $[13,45,46,107]$. In addition, it has been suggested that Thy-1 ${ }^{-}$IEL in mice may contain a lower than normal proportion of $\alpha \beta^{+}$T cells, while Thy-1 ${ }^{+}$IEL are normal in this respect [114]. Our own results also indicate that murine $\mathrm{CD} 8^{+}$IEL may express less $\alpha \beta$ TCR than other $\mathrm{CD}^{+} \mathrm{T}$ cells. Thus, the true frequency of different TcR among IEL remains unclear. It will be an important goal of future research to investigate the $\mathrm{T}$ cell lineage of IEL, using appropriate molecular biological and immunological techniques. In particular, it will be of interest to determine the relationship between $\mathrm{CD} 8{ }^{+} \mathrm{IEL}$ and the rare population of peripheral $\mathrm{CD} 8^{+} \mathrm{T}$ cells which has recently been described in man and which appears to represent a distinct subset of $\gamma \delta^{+}$ T lymphocytes [80].

Activation Markers on IEL. Many morphological features of IEL are consistent with a degree of activation in situ and several investigators have looked for the presence of phenotypic markers of activation on IEL. Most of these studies have been negative, as IEL do not express conventional $\mathrm{T}$ cell activation markers, including the interleukin 2 (IL 2) receptor (Tac; CD25) [45, 58], class II major histocompatibility complex (MHC) molecules (HLA-DP, DR, DQ) $[9,11,13$, $45,46,65,102,103$ ], transferrin receptors (CD9) [65] or T10 [9]. Nevertheless, some phenotypic features are not consistent with IEL being entirely a resting population of T cells. A variable proportion of human IEL express the CD7 marker normally associated with activated $\mathrm{T}$ lymphocytes and this is most marked among $\mathrm{CD}^{+}$IEL $[65,107]$. In addition, $50 \%-60 \%$ of murine IEL express the CT1 carbohydrate epitope of the T200 common leucocyte antigen, which is rarely found on resting peripheral $\mathrm{T}$ cells, but is present on many activated $\mathrm{T}$ cells, particularly those with cytotoxic activity $[51,58]$. More recently, these results have been supported by the fact that an IEL-specific monoclonal antibody, M290, seems to recognise an unusual form of the T200 molecule [50] and by the finding that most human IEL carry the UCHL-1 marker which is an epitope of the T200 molecule expressed primarily on differentiated memory T cells (J. Spencer and T. T. Mac- 
Donald, personal communication). These features indicate that IEL may have already interacted with antigen before entering the epithelium.

Other Phenotypic Markers on IEL. The preceding sections show clearly that the vast majority of IEL are T lymphocytes of undefined nature, but many studies have also identified a small population of IEL which do not express the CD3 marker (see above). Some of these CD3 ${ }^{-}$cells express other pan $\mathrm{T}$ cell markers [44, 107], while others will be the eosinophils, mast cells and macrophages rarely found in the epithelium. Despite the similarity between the morphology of IEL and the LGL which mediate NK cell activity in other sites, NK cell markers such as Leu-7 (HNK-1), NKH-1 (Leu-19) or the FcRIII receptor (CD16, Leu-11b) are almost never found on human IEL $[1,9,23,36,45,46,103]$. However, 15\%-20\% of mouse IEL express the asialo $G_{M 1}$ molecule $[8,112]$ which is often considered specific for rodent NK cells and I shall return to the issue of NK-active IEL in a later section. One final phenotypic peculiarity of IEL comes from recent reports that not all IEL carry LFA-1-related antigens found on most other lymphocytes $[13,58]$.

IEL-Specific Phenotypic Markers. The use of conventional lymphocyte markers has not yet elucidated the nature and lineage of IEL and several groups have attempted to resolve this issue by raising IEL-specific monoclonal antibodies. This has proved successful in mice, humans and rats and the reagents show many similarities.

The first marker of this type was described in rats [12], but the same group soon described a similar antibody which was highly reactive with human IEL. This antibody, HML-1 labels virtually all IEL, irrespective of their morphology and expression of the other lymphocyte markers described above $[13,45]$. Few cells in other tissues are $\mathrm{HML}-1^{+}$, although many of the $\mathrm{CD} 3^{+}$lymphocytes found in the epithelium of the breast, bronchus and uterus are $\mathrm{HML}-1^{+}$, underlining the possible relationship between IEL in different mucosae. Approximately $40 \%$ of LP lymphocytes are also HML- $1^{+}$and interestingly, most of these are CD8 ${ }^{+}$, as were the $20 \% \mathrm{HML}^{-1}{ }^{+}$cells found in foetal decidua. These findings indicate that HML-1 identifies a predominantly $\mathrm{CD} 8^{+}$population of lymphocytes which may localise preferentially in epithelia. The molecule recognised by HML-1 is a heterodimer with chains of molecular mass $105 \mathrm{kDa}$ and $150 \mathrm{kDa}$ [13] and is characteristic of one of the "integrin" molecules which are believed to mediate adhesion between cells in vivo. Thus, HML-1 may be a cell surface marker which enables IEL to interact within the surrounding epithelium. This may act in two ways. First, HML-1 could appear only after IEL enter the epithelium and so its function would be to retain IEL in this site. Alternatively, as HML-1 is expressed on MLN lymphoblasts, this molecule may direct the migration of IEL precursors to the epithelium. Another recently described monoclonal antibody has an almost identical pattern of specificity for murine IEL, CD8 ${ }^{+}$LP lymphocytes and some TDL blasts [50]. As this M290 antibody also recognised an integrin-line molecule, these findings underline the possible importance of cell surface adhesion molecules in regulating the appearance of $\mathrm{CD}^{+} \mathrm{T}$ cells in the epithelium. The development 
of further IEL-specific monoclonal antibodies will be of considerable help in defining the nature and origins of these cells.

\section{Functional Properties of IEL}

It has proved remarkably difficult to determine the functions of IEL (Table 2), partly because of the unusual phenotypic properties discussed above. Furthermore, methods for isolating pure populations of IEL have only become available comparatively recently and there are very few studies in man which have used IEL preparations of adequate purity. For these reasons, I shall confine my attention principally to animal work and will include only those human reports which used well-characterised populations of IEL.

Cytotoxic T Lymphocyte (CTL) Functions. The large number of CD8 ${ }^{+}$IEL of granular morphology would be consistent with the presence of many CTL. It is exceedingly difficult to examine for CTL function in man, but allospecific CTL appear rapidly in the LP and epithelium of mice immunised with allogeneic tumour cells $[17,52,87]$. Interestingly, CTL are found among IEL after either oral or parenteral immunisation and under these circumstances, IEL have as much or more CTL activity than cells from conventional lymphoid tissues. Paradoxically, more detailed in vitro studies have shown a low frequency of CTL precursors among IEL and most of these belong to the small population of Thy-1 $1^{+}$CD8 ${ }^{+}$IEL $[26$, 27]. These findings suggest that individual CTL among IEL may have very high lytic activity on a cell for cell basis and may indicate that cytotoxic IEL have been pre-activated in situ. This idea is supported by the fact that IEL share many features of cloned CTL, including their morphology, the presence of the murine CT1 antigen and their marked tendency to lose specificity during culture in vitro [53]. In addition, the asialo $\mathrm{G}_{\mathrm{M} 1}$ marker found on $15 \%-20 \%$ IEL may also be expressed by activated CTL [110]. Finally, compared with CD8 ${ }^{+}$lymphocytes from other tissues, resting mouse IEL seem to be more readily activated to exhibit CTL activity after stimulation with anti-CD3 antibody [35].

Table 2. Functional properties of IEL

\begin{tabular}{ll}
\hline Present & $\begin{array}{l}\text { Cytotoxic T cell activity } \\
\text { Lymphokine secretion (IFN- } \gamma, \text { IL 3, GM-CSF) } \\
\text { Local DTH responses }\end{array}$ \\
Low or absent & $\begin{array}{l}\text { NK cell activity -inducible } \\
\text { Proliferation in response to mitogens etc. } \\
\text { IL 2 production }\end{array}$ \\
Uncertain & Helper/suppressor T cell activity
\end{tabular}

IFN Interferon; $I L$ interleukin; GM-CSF granulocyte/macrophage-colony-stimulating factor; $D T H$ delayed-type-hypersensitivity; $N K$ natural killer 
Natural Cytotoxicity by IEL. NK cell-specific markers are virtually absent from human IEL (see above) and human IEL show no NK activity against conventional lymphoid tumour cell targets in conventional short-term assays, even when stimulated by IL 2 or interferon (IFN) [9, 90]. Although a similar lack of resting NK cell activity has been described in IEL from most other species $[8,34,58$, $86,95,114,117]$, IEL seem to contain a large number of cells which can bind to NK cell targets [34] and can express excellent NK activity if extended assays are used $[14,78,79,111]$. In addition, IEL from mice immunised with allogeneic tumour cells or with GvH reaction (R) have enhanced NK activity, even in shortterm assays [5, 87]. Finally, it has been shown that murine IEL may have nonspecific short-term lytic activity against target cells infected with the enteric pathogen, mouse hepatitis virus (MHV). This activity was non-antigen-specific and due to Thy-1 ${ }^{-}$CD8 ${ }^{-}$IEL and so did not reflect the degenerate CTL described above [8]. Similar non-specific cytotoxicity against Giardia trophozoites has been noted using mouse IEL [48] and against a crypt cell line using rat IEL [40]. Thus, IEL may mediate non-specific cytotoxicity directed at target structures different from those recognised by conventional NK cells, such as pathogens or intestinal cells themselves. In later sections, I shall describe evidence that IEL NK cells may be important in certain forms of local immunopathology.

Proliferative Capacity of IEL. The vast majority of IEL appear to be T lymphocytes and a characteristic property of $\mathrm{T}$ cells is an ability to proliferate in response to polyclonal mitogens and specific antigens. It is, therefore, intriguing that it has proved very difficult to demonstrate proliferative activity by IEL.

Most workers find that IEL normally fail to respond to polyclonal mitogens or alloantigens in vitro (Fig. 5) [12, 16, 49, 86, 87]. Although some positive responses have been reported using IEL from some animal species, they are usually much smaller than those obtained with lymphocytes from other tissues $[19,20$, 116, 120]. Human IEL bind the polyclonal mitogen concanavalin A (Con A) normally [36] and the lack of accessory cells among IEL preparations does not seem to account for their defective responses. Although we and others have found that addition of adherent accessory cells can enhance the response of IEL to mitogens or alloantigens $[19,88]$, the resulting responses remain poor and others have not found similar effects [36]. Furthermore, mouse IEL show very little response to phorbol ester and calcium ionophore, agents which activate all lymphocytes maximally in the absence of accessory cells [89]. This poor proliferative capacity appears mainly to be a property of $\mathrm{CD} 8^{+}$IEL [89] and there is a very low frequency of Con A-responsive CD8 ${ }^{+}$IEL compared with $\mathrm{CD}^{+}{ }^{+}$spleen cells [20]. Interestingly, however, human $\mathrm{CD}^{+}$LP lymphocytes may share this defective response to mitogens [23].

The low proliferative potential of IEL does not seem primarily to reflect a defective production of IL 2 . Although IEL produce little or no IL 2 in response to mitogens or alloantigens [12, 20, 23 117] addition of exogenous IL 2 does not raise their proliferative response to anywhere near normal levels. Furthermore, IEL produce adequate amounts of IL 2 when optimally stimulated with phorbol ester and ionophore or via the CD2 antigen [23, 89]. The defective proliferative 


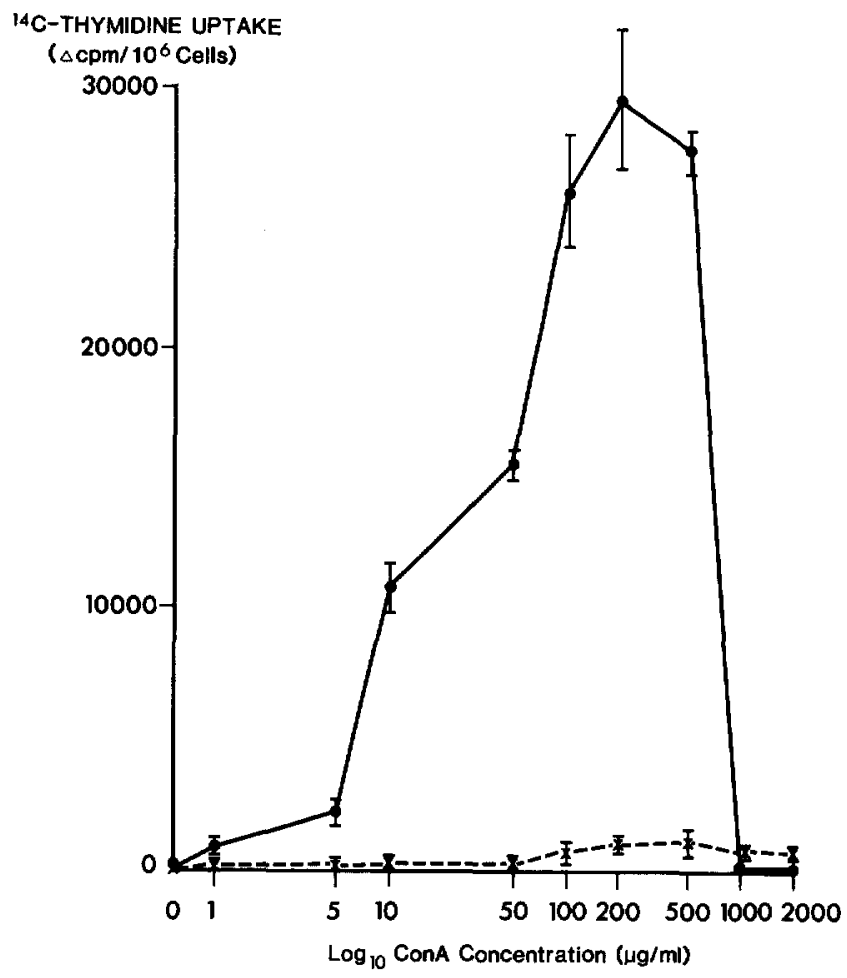

Fig. 5. Failure of murine IEL to proliferate in response to the $T$ cell mitogen concanavalin A. Spleen cells make an excellent proliferative response over a range of mitogen concentrations, whereas IEL show little response above background. - Spleen, --- IEL

response of IEL, therefore, appears to reflect an absence of IL 2-responsive IEL, particularly within the $\mathrm{CD} 8^{+}$population. As peripheral $\mathrm{CD} 8^{+} \mathrm{T}$ cells frequently respond very efficiently to $I L 2$ [25], this again emphasises the unusual nature of $\mathrm{CD}^{+}$IEL.

One intriguing study in man suggests that it may be possible to overcome this proliferative defect by activating IEL through the CD2 molecule. In this work, IEL normally made no response to several polyclonal mitogens, but excellent proliferation could be obtained in presence of sheep red blood cells (SRBC) [23]. This effect could be blocked by antibodies against the CD2 marker, which forms the receptor for SRBC found on human T cells. Equivalent CD2-specific reagents have not been available to confirm this report in other species. However, these findings could indicate that IEL have unusual requirements for proliferation, either due to inherent differences in cellular metabolism or perhaps due to their particular level of differentiation in situ.

There are virtually no reports of antigen-specific proliferation by IEL from any species. Indeed, we have never been able to obtain responses by IEL to either soluble or cellular antigens after either oral or parenteral immunisation of mice, even under circumstances when IEL can mediate other functions such as cyto- 
toxicity or delayed-type hypersensitivity (DTH) (see below). Similarly, it has been reported that non-human primate IEL fail to proliferate in response to lymphogranuloma venereum, even in immune animals and when mucosal lymphocytes can act as antigen-specific helper $T$ cells [120].

Production of Lymphokines by IEL. As noted earlier, most studies find that IEL do not produce IL 2 when stimulated by mitogens. Nevertheless, there is one report that human IEL may produce IL 2 normally when stimulated with phytohemagglutinin (PHA) [23], while murine IEL produce IL 2 when stimulated by a GvHR in vivo or optimally with phorbol ester and ionophore in vitro [39, 89]. It seems reasonable to conclude that IEL may be capable of IL 2 production under certain circumstances, but that this activity is normally low and may well be associated with subpopulations of IEL.

Rodent and pig IEL stimulated with mitogens have been shown to produce soluble mediators with IFN-like activity. Much of this material appears to have the properties of IFN- $\gamma$, including the ability to induce MHC class II molecules on colonic epithelial cells $[10,20,117]$. Polyclonally activated mouse IEL may also produce IL 3 and granulocyte/macrophage-colony-stimulating factor, while antigen-specific lymphokine production has been found using IEL from mice infected with Trichinella spiralis [21]. IEL from mice with GvHR also produce more IL 2, IL 3 and IFN [39]. Interestingly, CD8 ${ }^{+}$IEL seem to participate in lymphokine production. Nevertheless, the levels of lymphokines produced by IEL are usually low when compared with other lymphoid cells and its significance must remain speculative. As yet, there are no equivalent studies with human IEL.

Other Immunological Functions of IEL. The presence of the CD7 marker on human $\mathrm{CD}^{+}{ }^{+}$small bowel IEL has been used to suggest that IEL act as suppressor $\mathrm{T}$ cells $\left(\mathrm{T}_{\mathrm{s}}\right)$ and are involved in the unusual ability of orally administered antigens to induce immunological tolerance [65]. However, the limited studies which have been performed on $\mathrm{T}_{\mathrm{s}}$ activity by IEL argue against this idea. Human IEL do not suppress PHA responses by PBL [23] and have only a moderate ability to suppress polyclonal Ig production by pokeweed mitogen (PWM)-stimulated PBL, identical to that found using PBL [36]. Furthermore, work in rats showed that IEL could not transfer the tolerant state when taken from animals fed ovalbumin. This contrasted with the transferable, antigen-specific $T_{s}$ activity found in Peyer's patch cells in the same experiments [62]. Thus, there is no evidence at present that IEL are enriched for $\mathrm{T}_{\mathrm{s}}$.

Human IEL have also been shown to act as helper cells for PWM-induced production of $\mathrm{Ig}$ in vitro, but as before, this activity mimicked that found with other lymphocytes and its significance was unclear [36]. There are no other reports of helper $\mathrm{T}$ cell activity by IEL.

One surprising activity which has been reported using murine IEL is an ability to transfer antigen-specific DTH activity from immunised animals. As with IEL mediating CTL activity, DTH effector cells appeared in IEL after both oral and parenteral immunisation with protein antigens (Fig. 6) [104]. The ability of IEL to transfer DTH was greater than that found in other intestinal lymphoid tissues and was almost as potent as that found in peripheral lymph nodes draining a site 


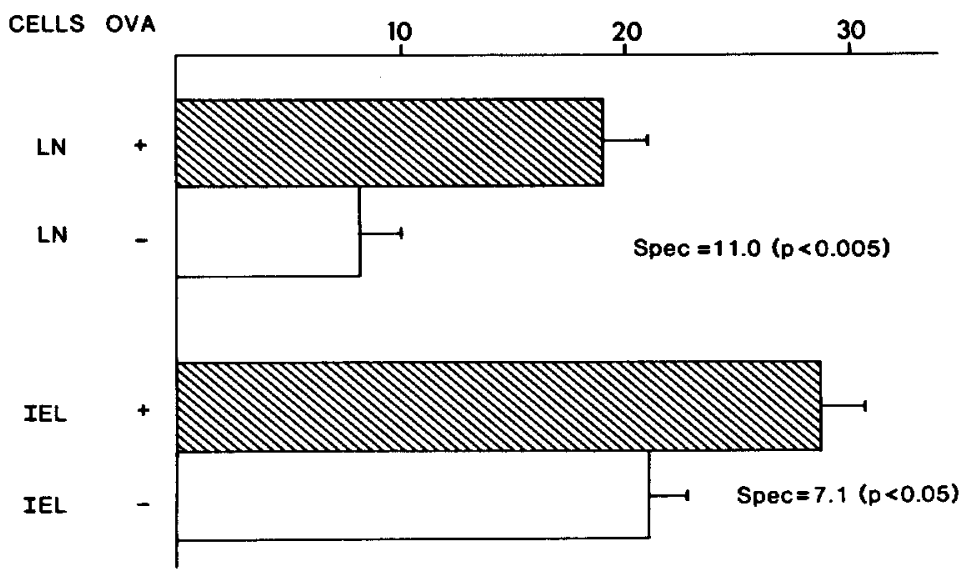

Fig. 6. Adoptive transfer of antigen-specific delayed-type hypersensitivity (DTH) by IEL. Draining lymph node $(L N)$ cells and IEL were taken from mice immunised into a footpad with ovalbumin (OVA) in adjuvant and transferred with (open bars) or without (hatched bars) OVA intradermally into syngeneic recipients. The DTH response is measured by the increase in footpad thickness $24 \mathrm{~h}$ after cell transfer and the specific activity is the response with OVA less that without OVA

immunised with adjuvant (Fig. 6). Although the poor yield of isolated IEL has limited further studies of this type, mouse IEL have also been found to produce a local GvHR in the popliteal lymph node after transfer into the footpad of semiallogeneic hosts [2,19]. This local GvHR reflects non-specific activation and recruitment of host cells similar to that found in a DTH reaction, supporting the in vitro evidence that IEL are capable of secreting lymphokines.

\section{Biological Role of IEL}

It is obviously difficult to ascribe an in vivo role to IEL in view of their unusual phenotype and the limited amount of positive functional information available. In addition, few studies have examined directly the involvement of IEL in mucosal immune responses in vivo. Nevertheless, there is considerable circumstantial evidence from both clinical and experimental work that IEL may indeed play an important role in local immunity.

\section{IEL in Immunopathology}

Alterations in Number and Morphology in Clinical Enteropathy. A role for IEL in local pathology has often been implied from evidence that there is an increased population of IEL in several enteropathies (Table 3), but the interpretation of these findings is confused by controversy over how to enumerate IEL in tissue sections. In 1971, Ferguson and Murray [30] suggested that IEL numbers should be expressed as a ratio of the number of enterocytes and presented evidence that this ratio was greatly increased in coeliac disease. This observation has since been 
amply confirmed and similar increases in IEL/100 epithelial cells have been reported in cow's milk protein intolerance, giardiasis, tropical sprue, dermatitis herpetiformis and in the active lesions of Crohn's disease [24, 28, 54-56, 73, 96, 99, 119]. Unconfirmed reports also suggest a high IEL count in AIDS [22], Whipple's disease, the enteropathy of agammaglobulinaemia and in some cases of blind loop syndrome [73].

Other workers have challenged the interpretation of these findings by suggesting that the absolute number of IEL is not increased in enteropathy. These objections are based on the fact that the villus atrophy found in the relevant disorders leads to a decreased number of enterocytes and, hence, produces an apparent increase in the IEL : enterocyte ratio. Indeed, when IEL are enumerated with reference to a constant area or volume of mucosa, their absolute number is actually decreased in e.g. coeliac disease [16, 68, 71, 91]. Nevertheless, it should be noted that increased ratios of IEL are found in experimental enteropathies in the absence of enterocyte loss (see below), while an increased absolute IEL count has been observed in the crypts of patients with established coeliac disease and more generally, soon after gluten challenge $[59,71,72]$. These features indicate that a direct role for IEL cannot be dismissed simply on numerical grounds. Furthermore, the enumeration of IEL with respect to enterocytes remains the simplest and most rapid means of assessing this population. The results obtained provide useful diagnostic information even in the presence of villus atrophy and, in its absence, may provide an accurate estimate of the absolute size of the population.

Irrespective of the number of IEL found in enteropathy, there is considerable evidence that an increased proportion of IEL are activated under these conditions. In coeliac disease, IEL are increased in size and more have a blast-like or activated morphology $[91,92]$. In parallel, there is an increased flux of IEL across the BM $[68,70,71]$ and their mitotic index is increased $[31,71,72]$. This increased turnover and activation of IEL is not restricted to coeliac disease and parallels exactly the increased IEL count found in many other enteropathies [29, 31]. These findings emphasise the possible involvement of activated IEL in local disease.

Phenotype of IEL in Enteropathy. Until recently, it seemed that these morphological and dynamic changes were not mirrored by major changes in the

Table 3. Clinical enteropathies associated with increased counts of IEL

\author{
Coeliac disease \\ Dermatitis herpetiformis \\ Cow's milk protein intolerance \\ Other food-sensitive enteropathies \\ Crohn's disease \\ Graft-versus-host disease \\ AIDS \\ Tropical sprue \\ Giardiasis \\ Other infective diarrhoeas (rare)
}


phenotype of IEL during enteropathy. Even in untreated coeliac disease, IEL do not express T cell activation markers such as MHC class II or IL 2 receptors and the proportion of $\mathrm{CD}^{+}$and $\mathrm{CD}{ }^{+}$cells remains the same $[49,65,103,107]$. Furthermore, IEL retain the IEL-specific marker HML-1 [107] and virtually all continue to be $\mathrm{CD}^{+}{ }^{+} \mathrm{T}$ cells $[46,107]$ with no infiltration by NK cells $[1,46$, 103]. However, some subtle phenotypic changes have been detected in coeliac IEL, with an increased expression of CD5 by CD8 ${ }^{+}$IEL and an increased number of IEL expressing the T2 blast antigen [46, 65, 103]. The significance of these changes is unclear, although they have been ascribed to activation of IEL.

Very recent studies have suggested that more profound alterations in the population of IEL may be occurring in enteropathy. Thus, it has been reported that the proportion of $\mathrm{CD}^{+}{ }^{+} \mathrm{CD} 4{ }^{-} \mathrm{CD} 8{ }^{-}$IEL may rise to around $30 \%$ in both untreated and treated coeliac disease. In parallel, there is a loss of the minority population of $\mathrm{CD} 7{ }^{+} \mathrm{CD} 3^{-}$IEL and an increase in the number of IEL expressing the $\gamma \delta$ form of the TcR [107]. These intriguing findings provide some evidence that an unusual population of $\mathrm{T}$ cells may be infiltrating the epithelium in coeliac disease.

IEL in Experimental Models of Enteropathy. The functions of IEL in clinical enteropathy are unknown and have not been studied using IEL from diseased intestine. Nevertheless, certain experimental models of enteropathy appear to involve IEL and may help provide relevant information on the pathological role of IEL. Increased numbers of IEL are found in allograft rejection of gut, in the intestine of mice with experimental GvHR, during local DTH responses to orally administered protein antigens and in murine giardiasis [5, 28, 32, 64, 82-85]. In addition, the induction of enteropathy in human foetal intestinal organ cultures by activation of mucosal $\mathrm{T}$ cells is associated with maintained infiltration by IEL [79].

The increased IEL count in GvHR is a very early occurrence and parallels the other proliferative features of the disease, including crypt hyperplasia and hypertrophy of the lymphoid system $[5,85]$. The infiltrating IEL have an increased mitotic activity [29] and appear to derive from precursors in Peyer's patches [38]. In general, their phenotype mirrors that of normal IEL, although there may be a loss of IEL-specific markers $[39,50]$. It seems that host IEL are recruited nonspecifically by the anti-host DTH response which characterises the early phase of GvHR. As IEL from mice with GvHR and $T$. spiralis infection have been found to secrete IFN- $\gamma$, IL 3 and IL $2[21,39]$, it is possible that activated IEL contribute to the intestinal pathology by releasing the mediators thought to be important for this form of enteropathy [29, 82]. An alternative role for IEL is suggested by their increased NK activity in mice with GvHR [5] and interestingly, depletion of NK cells in vivo not only prevents intestinal GvHR but reduces the IEL count [81]. Although these findings contrast with the lack of NK cells in the epithelium of patients with coeliac disease, the experimental studies do indicate some of the functions which might warrant investigation under clinical conditions.

IEL in Malignancy. Primary tumours of the small intestine are rare and studies of the IEL present in carcinomas of the stomach or colon reveal few alterations 
in appearance or function [45]. Nevertheless, it has recently become apparent that the small bowel tumours once referred to as "malignant histiocytosis of the intestine" are in fact T cell lymphomas which arise from IEL. The malignancy frequently originates in the epithelium and the tumour cells are granulated $\mathrm{T}$ cells [42, 100], which express CD7 and the IEL-specific marker HML-1 [100]. They frequently express CD3, but not CD4 or CD8 $[100,106]$ and, hence, their phenotype is remarkably similar to that of the abnormal IEL which infiltrate the epithelium in coeliac disease. These $T$ cell lymphomas produce an identical pattern of enteropathy to coeliac disease and it has long been suspected that the two conditions are related. This idea is supported by the recent demonstration that CD4 ${ }^{-} \mathrm{CD}^{-}{ }^{-} \mathrm{HML}-1^{+}$IEL are abundant in unaffected intestine of patients with both coeliac disease and $T$ cell lymphoma [107] and it may be that these rare tumours may help understand the role of IEL in several clinical enteropathies.

Protective Role of IEL. In the previous section, I discussed the possibility that IEL are important in local immunopathology. As one of these conditions is intestinal parasite infections, the question arises as to whether IEL are involved in protective responses against local pathogens. Their close proximity to luminal antigens certainly makes IEL ideal candidates for such a function and increased IEL counts are found in several human infectious disorders, including giardiasis and tropical sprue. One report suggested that IEL may actually leave the epithelium to attack giardia trophozoites [93] but this has not been confirmed in other conditions and its significance is unclear. The ways in which IEL could mediate protective immunity are also unknown, but, as noted above, murine IEL have been found to have potent NK activity against the enteric virus, MHV. When these NK-active IEL are depleted in vivo, viral clearance is markedly inhibited, implying an important role for IEL NK cells in the anti-viral response [8]. It would be of interest to examine for other specific and non-specific functions of IEL from clinical and experimental infections.

\section{Summary and Conclusions}

IEL are one of the largest and least understood populations of lymphocytes with many unique features, including their morphology, phenotype and functional characteristics. Many IEL have the appearance of LGL but few have the phenotype of NK cells and their resting NK activity is low. Similarly, it is now clear that virtually all IEL are $\mathrm{CD} 3^{+} \mathrm{T}$ lymphocytes, but there are many differences between IEL and other T cell populations, including those in the LP. Almost $75 \%$ of IEL are $\mathrm{CD}^{+}$and many of these do not express certain pan $\mathrm{T}$ cell markers found on conventional $\mathrm{T}$ lymphocytes. IEL do not recirculate through lymphoid tissues in vivo [2], normally do not produce IL 2, and have little or no proliferative capacity in vitro. They can act as specific CTL, may mediate local DTH responses and can secrete certain lymphokines, including IL 3 and IFN- $\gamma$. Finally, recent studies indicate that IEL express specific surface markers not found on most other lymphocytes and in some species IEL may use a form of the TcR differing from that expressed by normal, mature $\mathrm{T}$ cells. 
This latter finding has been interpreted as evidence that IEL belong to a family of primitive epithelial T cells which use the $\gamma \delta \mathrm{TcR}$ and whose function is to defend body surfaces such as the skin, gut and respiratory tract. This is an attractive hypothesis which deserves further investigation. Nevertheless, it should be emphasised that the function of $\gamma \delta^{+} \mathrm{T}$ cells is entirely unknown. Current evidence indicates that the $\gamma \delta \mathrm{TcR}$ is expressed mainly on developing T cells and has extremely limited diversity of recognition. Thus, it is difficult to envisage how IEL using this TcR could be of use in mediating efficient immune responses against the wide range of antigens likely to be encountered in the gut. Finally, we and others have been unable to confirm the high proportion of $\gamma \delta$ TcR among human or murine IEL and this question will obviously be the focus for much work in the near future.

Our own interpretation of the unusual properties of IEL is that they represent a population of committed effector cells which have already been activated in situ (Table 4). This concept is supported by many of their morphological features and is consistent with the presence of certain phenotypic markers of activation. Furthermore, the motile appearance of IEL in vivo and high locomotor activity in vitro [2], as well as their ability to accumulate in inflamed tissues (Table 4), is consistent with an activation level above the resting state. As IEL are not in mitosis and do not express activation markers such as IL 2 receptors and MHC class II molecules, they are clearly not true lymphoblasts. Rather, we propose that IEL are the $\mathrm{T}$ lymphocyte equivalent of plasma cells and are end-stage effector cells which have differentiated fully before entering the epithelium. As a result and, as has been reported, IEL would not be capable of further proliferation when restimulated with mitogens, but would mediate effector functions such as CTL activity, DTH responses or secretion of inflammatory mediators. According to this hypothesis, the increased numbers of activated IEL in local disease means they have an important role as immune effector cells. We would predict that IEL are recruited non-specifically by other local $\mathrm{T}$ cells during such responses and

Table 4. Migration of ${ }^{51} \mathrm{Cr}$-labelled IEL and mesenteric lymph node (MLN) lymphocytes into lymph nodes and ear skin of normal mice and of mice sensitised on the ears with oxazolone

\begin{tabular}{lllc}
\hline Tissue & Oxazolone & IEL & MLN Cells \\
\hline MLN & - & $0.37 \pm 0.01$ & $7.4 \pm 0.9$ \\
Auricular LN & - & $0.29 \pm 0.01$ & $3.0 \pm 0.7$ \\
& + & $0.31 \pm 0.02$ & $12.2 \pm 1.0^{*}$ \\
Ear & - & $0.2 \pm 0.005$ & $0.25 \pm 0.02$ \\
& + & $0.74 \pm 0.11^{*}$ & $0.37 \pm 0.06$ \\
\hline
\end{tabular}

Intravenously injected IEL do not accumulate in either intestinal (MLN) or peripheral lymph nodes (auricular LN), even if these are draining oxazolone-inflamed skin. However, IEL accumulate fairly well in inflamed ear skin itself. In contrast, MLN cells accumulate readily in normal lymph nodes and this is increased in lymph nodes draining inflamed skin. MLN show little ability to migrate into inflamed ears

$* P<0.001$ vs unstimulated tissue 
that their function is to amplify, rather than initiate mucosal immune reactions. These possibilities remain to be investigated at the cellular level.

Two alternative, but highly speculative, roles of IEL remain to be considered (Table 5). First, IEL may have been functionally inactivated by a first encounter with antigen, either because of their expression of unusual $T c R$ or because of inappropriate antigen presentation within the mucosa. Small bowel enterocytes have the ability to express MHC class II antigens and there is some evidence that $\mathrm{Ia}^{+}$ enterocytes may be able to act as accessory cells for $T$ cells $[3,74]$. Recent studies indicate that when MHC class II-expressing tissue cells from skin or pancreas present antigen to normal $\mathrm{T}$ cells, full $\mathrm{T}$ cell activation does not occur, probably due to the inability of tissue cells to produce all the accessory signals normally required for $T$ cell growth [47]. T cells treated in this way show some signs of partial activation, including morphological alterations and production of IL 3 and IFN- $\gamma$, but not IL 2. These cells are then unresponsive to further stimulation with antigen. It is tempting to speculate that IEL are locked in a similar state of partial activation in situ and that this lympho-epithelial compartment has evolved to prevent harmful hypersensitivity reactions within this important tissue. The increased number of IEL in disease may, therefore, reflect an attempt by the local immune system to inhibit local immune responses by flooding the area with anergic lymphocytes. As with previous suggestions that MHC class II-expressing enterocytes may activate a population of $\mathrm{CD}^{+} \mathrm{T}_{\mathrm{s}}$ among IEL [3, 74], this hypothesis has to be reconciled with the dogma that a $\mathrm{CD}^{+}$population such as IEL should not recognise antigen in the context of MHC class II molecules. Furthermore, it does not explain how the epithelial lymphoid system can differentiate between beneficial antigens such as foods and other, more harmful ones, such as pathogens. Nevertheless, the relationship between IEL and surrounding enterocytes is an intriguing area for future investigation.

Lastly, the possibility exists that the gut epithelium is a site for extrathymic $T$ cell differentiation, as was first suggested many years ago [33]. Most IEL are clearly TDL which are influenced markedly by the presence of local antigen. Nevertheless, the presence of a variable number of IEL with the immature, $\gamma \delta$ form of the $T c R$ raises the question as to whether some $T$ cell precursors may enter the epithelium and undergo aberrant education in this site. It is, therefore, interesting that many of the "activation" markers found on IEL, including CTI, UCHLI and CD7 are also found on thymocytes. As many of these concepts may soon prove amenable to the rapidly developing methods of molecular biology and cellular immunology, the biological role of IEL may prove to be less enigmatic within the near future.

Table 5. Speculative biological functions and roles of IEL

\begin{tabular}{ll}
\hline Function & Role \\
\hline Differentiated effector T cells & Mucosal defence/pathology \\
Anergic T cells & Prevent local hypersensitivity \\
Unique T cell lineage & Extrathymic education \\
\hline
\end{tabular}




\section{References}

1. Arato A, Savilahti E, Tainio V-M, Verkasalo M, Klemola T (1987) HLA-DR expression, natural killer cells and IgE containing cells in the jejunal mucosa of coeliac children. Gut 28: 988

2. Baca ME, Mowat AMcI, MacKenzie S, Parrott DMV (1987) Functional characteristics of intraepithelial lymphocytes from mouse small intestine. III. Inability of intraepithelial lymphocytes to induce a systemic graft-versus-host reaction is because of failure to migrate in vivo. Gut 28: 1267

3. Bland PW, Warren LG (1986) Antigen presentation by epithelial cells of rat small intestine. II. Selective induction of suppressor $\mathrm{T}$ cells. Immunology 58: 9

4. Bonneville M, Janeway CA, Ito K, Haser W, Ishida I, Nakanishi N, Tonegawa S (1988) Intestinal intraepithelial lymphocytes are a distinct set of $\gamma \delta \mathrm{T}$ cells. Nature 336: 479

5. Borland A, Mowat AMcI, Parrott DMV (1983) Augmentation of intestinal and peripheral natural killer cell activity during the graft-versus-host reaction in mice. Transplantation $36: 513$

6. Bradley JA, Mason DW, Morris PJ (1985) Evidence that renal allografts are rejected by cytotoxic $T$ cells and not by nonspecific effectors. Transplantation 39: 169

7. Bucy RP, Chen C-LH, Cihak J, Losch U, Cooper MD (1988) Avian T cells expressing $\gamma \delta$ receptors localize in the splenic sinusoids and the intestinal epithelium. J Immunol 141: 2200

8. Carman PS, Ernst PB, Rosenthal KL, Clark DA, Befus AD, Bienenstock J (1986) Intraepithelial leukocytes contain a unique subpopulation of NK-like cytotoxic cells active in the defence of gut epithelium to enteric murine coronavirus. J Immunol 136: 1548

9. Cerf-Bensussan N, Schneeberger EE, Bhan AK (1983) Immunohistologic and immunoelectron microscopic characterisation of the mucosal lymphocytes of human small intestine by the use of monoclonal antibodies. J Immunol 130: 2615

10. Cerf-Bensussan N, Quaroni A, Kurnick JT, Bhan AT (1984) Intraepithelial lymphocytes modulate Ia expression by intestinal epithelial cells. J Immunol 132: 2244

11. Cerf-Bensussan N, Guy-Grand D, Griscelli C (1985) Intraepithelial lymphocytes of human gut: isolation, characterisation and study of natural killer activity. Gut 26: 81

12. Cerf-Bensussan N, Guy-Grand D, Lisowska-Grospierre B, Griscelli C, Ghan AK (1986) A monoclonal antibody specific for rat intestinal lymphocytes. J Immunol 136: 76

13. Cerf-Bensussan N, Jarry A, Brousse N, Lisowska-Grospierre B, Guy-Grand D, Griscelli C (1987) A monoclonal antibody (HML-1) defining a novel membrane molecule present on human intestinal lymphocytes. Eur J Immunol 17: 1279

14. Chai J-Y, Lillehoj HS (1988) Isolation and functional characterisation of chicken intestinal intraepithelial lymphocytes showing natural killer cell activity against tumour target cells. Immunology 63: 111

15. Collan Y (1972) Characteristics of non-epithelial cells in the epithelium of normal rat ileum: a light and electron microscopial study. Scand J Gastroenterol 7 [Suppl]: 18

16. Corazza GR, Frazzoni M, Gasbarrini G (1984) Jejunal intraepithelial lymphocytes in coeliac disease: are they increased or decreased? Gut 25: 158

17. Davies MDJ, Parrott DMV (1981) Cytotoxic T cells in small intestinal epithelial, lamina propria and lung lymphocytes. Immunology $44: 367$

18. Davies MDJ, Parrott DMV (1981) Preparation and purification of lymphocytes from the epithelium and lamina propria of murine small intestine. Gut 22: 481

19. Dillon SB, MacDonald TT (1984) Functional properties of lymphocytes isolated from murine small intestinal epithelium. Immunology 52: 501

20. Dillon SB, MacDonald TT (1986) Functional characterisation of Con A responsive Ly-2 positive mouse small intestinal intraepithelial lymphocytes. Immunology 59: 389

21. Dillon SB, Dalton BJ, MacDonald TT (1986) Lymphokine production by mitogen and antigen activated mouse intraepithelial lymphocytes. Cell Immunol 103: 326

22. Dobbins WO (1986) Human intestinal intraepithelial lymphocytes. Gut 27: 972

23. Ebert EC, Roberts AI, Brolin RE, Raska K (1986) Examination of the low proliferative capacity of human jejunal intraepithelial lymphocytes. Clin Exp Immunol 65: 148

24. Entrican JH, Busuttil A, Ferguson A (1984) Histopathological features of focal lesions in the jejunal mucosa in Crohn's disease are consistent with a cell-mediated immune response. Gut 25: A1145 
25. Erard F, Nabholz M, Dupuy-D'Angeac A, MacDonald HR (1986) Differential requirements for the induction of interleukin 2 responsiveness in $\mathrm{L} 3 \mathrm{~T} 4^{+}$and $\mathrm{Ly}-2^{+} \mathrm{T}$ cell subsets. J Exp Med 162: 1738

26. Ernst PB, Befus AD, Bienenstock J (1985) Leukocytes in the intestinal epithelium: an unusual immunological compartment. Immunol Today 6: 50

27. Ernst PB, Clark DA, Rosenthal KL, Befus AD, Bienenstock J (1986) Detection and characterisation of cytotoxic $\mathrm{T}$ lymphocyte precursors in the murine intestinal intraepithelial leucocyte population. J Immunol 136: 2121

28. Ferguson A (1977) Intraepithelial lymphocytes of the small intestine. Gut 18: 921

29. Ferguson A (1987) Models of immunologically-driven small intestinal damage. In: Marsh MN (ed) Immunopathology of the small intestine. Wiley, Chichester, pp 225

30. Ferguson A, Murray D (1971) Quantitation of intraepithelial lymphocytes in human jejunum. Gut 12: 988

31. Ferguson A, Ziegler K (1986) Intraepithelial lymphocyte mitosis in a jejunal biopsy correlates with intraepithelial lymphocyte count, irrespective of diagnosis. Gut 27: 675

32. Ferguson A, McClure JP, Townley RR (1976) Intraepithelial lymphocyte counts in small intestinal biopsies from children with diarrhoea. Acta Paediatr Scand 65: 541

33. Fichtelius KE (1968) The gut epithelium-a first level lymphoid organ? Exp Cell Res 49: 87

34. Flexman JP, Shellam GR, Mayrhofer G (1983) Natural cytotoxicity, responsiveness to interferon and morphology of intraepithelial lymphocytes from the small intestine of the rat. Immunology 48: 733

35. Goodman T, Lefrancois L (1988) Expression of the $\gamma \delta$ T-cell receptor on intestinal CD8 ${ }^{+}$ intraepithelial lymphocytes. Nature 333: 855

36. Greenwood JH, Austin LL, Dobbins WO (1983) In vitro characterisation of human intestinal intraepithelial lymphocytes. Gastroenterology 85: 1023

37. Groscurth P, Qiao B-Y, Podack ER, Hengartner H (1987) Cellular localisation of perforin 1 in murine cloned cytotoxic T lymphocytes. J Immunol 138: 2749

38. Guy-Grand D, Griscelli C, Vassalli $P(1978)$ The mouse gut T-lymphocyte, a novel type of T-cell: nature, origin and traffic in mice in normal and graft-versus-host conditions. J Exp Med 148: 1661

39. Guy-Grand D, Vassalli P (1986) Gut injury in mouse graft-versus-host reaction. Study of its occurrence and mechanisms. J Clin Invest 77: 1584

40. Hanglow AC, Perdue MH, Dyck N, Bienenstock J (1988) No evidence for cytotoxicity against epithelial cells by local intestinal lymphocytes in rat models of intestinal inflammation. In: MacDermott RP (ed) Inflammatory bowel disease: current status and future approach. Excerpta Medica, New York, pp 125

41. Huntley JF, McGorum B, Newlands GFJ, Miller HRP (1984) Granulated intraepithelial lymphocytes: their relationship to mucosal mast cells and globule leucocytes in the rat. Immunology 53: 525

42. Isaacson PG, O'Connor NTJ, Spencer J et al. (1985) Malignant histiocytosis of the intestine: a $\mathrm{T}$ cell lymphoma. Lancet I: 688

43. Janeway CA, Jones B, Hayday AC (1988) Specificity and function of T cells bearing $\delta$ receptors. Immunol Today 9: 73

44. Janossy G, Montano L, Selby WS, Duke O, Panayi G, Lampert I, Thomas JA, Granger S, Bofill M, Tidman N, Thomas HC, Goldstein G (1982) T cell subset abnormalities in tissue lesions developing during autoimmune disorders, viral infection, and graft-vs.-host disease. J Clin Immunol 2 [Suppl]: 425

45. Jarry A, Cerf-Bensussan N, Brousse N, Guy-Grand D, Muzeau F, Potet F (1988) Same peculiar subset of HML-1 ${ }^{+}$lymphocytes present within normal intestinal epithelium is associated with tumoral epithelium of gastrointestinal carcinomas. Gut 29: 1632

46. Jenkins D, Goodall A, Scott BB (1986) T-lymphocyte populations in normal and coeliac small intestinal mucosa defined by monoclonal antibodies. Gut 27: 1330

47. Jenkins MK, Schwartz RH (1987) Antigen presentation by chemically modified splenocytes induces antigen-specific $\mathrm{T}$ cell unresponsiveness in vitro and in vivo. J Exp Med 165 302

48. Kanwar SS, Ganguly NK, Walia BNS, Mahajan RC (1986) Direct and antibody-dependent cell- 
mediated cytotoxicity against Giardia lamblia by splenic and intestinal lymphoid cells in mice. Gut 27: 73

49. Kelly J, O'Farrelly C, O'Mahony C, Weir DG, Feighery C (1987) Immunoperoxidase demonstration of the cellular composition of the normal and coeliac small bowel. Clin Exp Immunol 68: 177

50. Kilshaw PJ, Baker KC (1988) A unique surface antigen on intraepithelial lymphocytes in the mouse. Immunol Lett 18: 149

51. Klein JR (1986) Ontogeny of the Thy-1 ${ }^{-} \mathrm{Ly}-2^{+}$intraepithelial lymphocyte. Characterisation of a unique population of thymus-independent cytotoxic effector cells in the intestinal mucosa. J Exp Med 164: 309

52. Klein JR, Kagnoff MF (1984) Nonspecific recruitment of cytotoxic effector cells in the intestinal mucosa of antigen-primed mice. J Exp Med 160: 1931

53. Klein JR, Kagnoff MF (1987) Spontaneous in vitro evolution of lytic specificity of cytotoxic T lymphocyte clones isolated from murine intestinal epithelium. J Immunol 138: 58

54. Kosnai I, Kuitunen P, Savilahti E, Rapola J, Kohegyi J (1980) Cell kinetics in the jejunal crypt epithelium in malabsorption syndrome with cow's milk protein intolerance and in coeliac disease of childhood. Gut 21: 1041

55. Kosnai I, Karpati S, Savilahti E, Verkasalo M, Bucsky P, Torok E (1986) Gluten challenge in children with dermatitis herpetiformis: a clinical, morphological and immunohistological study. Gut 27: 1464

56. Labo G, Gasbarrini G, Migli F, Bernardi M (1978) Thelio- and propriolymphocytes count in normal subjects and in primary and secondary enteropathy. GEN 32: 403

57. Lawn AM, Rose ME (1982) Mucosal transport of Eimeria tenella in the cecum of the chicken. J Parasitol 68: 1117

58. Lefrancois L (1987) Carbohydrate differentiation antigens of murine $T$ cells: expression on intestinal lymphocytes and intestinal epithelium. J Immunol 138: 3375

59. Leigh RJ, Marsh MN, Crowe P, Kelly C, Garner V, Gordon D (1985) Studies of intestinal lymphoid tissue. IX. Dose-dependent, gluten-induced lymphoid infiltration of coeliac jejunal epithelium. Scand J Gastroenterol 20:715

60. Lemmel E-M, Fichtelius KE (1971) Life span of lymphocytes within intestinal epithelium, Peyer's Patch epithelium, epidermis and liver of mice. Int Arch Allergy Appl Immunol 41: 716

61. Lyscom N, Brueton MJ (1982) Intraepithelial, lamina propria and Peyer's patch lymphocytes of the rat small intestine: isolation and characterisation in terms of immunoglobulin markers and receptors for monoclonal antibodies. Immunology 45: 775

62. Lyscom N, Brueton MJ (1983) Study of the transfer of tolerance by mucosal intraepithelial and Peyer's patch lymphocytes. Gut 24: A473

63. Lyscom N, Brueton MJ (1983) The development of intraepithelial and Peyer's patch lymphocyte subtypes in the small intestine of newborn rats. Clin Exp Immunol 54: 158

64. MacDonald TT, Ferguson A (1976) Hypersensitivity reactions in the small intestine. 2. Effects of allograft rejection on mucosal architecture and lymphoid cell infiltrate. Gut 17:81

65. Malizia G, Trejdosiewicz LK, Wood GM, Howdle PD, Janossy G, Losowsky MS (1985) The microenvironment of coeliac disease: $T$ cell phenotypes and expression of the $T 2$ " $T$ blast" antigen by small bowel lymphocytes. Clin Exp Immunol 60: 437

66. Marsh MN (1975) Studies of intestinal lymphoid tissue. I. Electron microscopic evidence of "blast transformation" in epithelial lymphocytes of mouse small intestinal mucosa. Gut 16: 665

67. Marsh MN (1975) Studies of intestinal lymphoid tissue. II. Aspects of proliferation and migration of epithelial lymphocytes in the small intestine of mice. Gut 16: 674

68. Marsh MN (1980) Studies of intestinal lymphoid tissue. III. Quantitative analyses of epithelial lymphocytes in the small intestine of human control subjects and of patients with coeliac sprue. Gastroenterology 79: 481

69. Marsh MN (1982) Studies of intestinal lymphoid tissue. IV. The predictive value of raised mitotic indices among jejunal epithelial lymphocytes in the diagnosis of gluten-sensitive enteropathy. J Clin Pathol 35: 517

70. Marsh MN (1985) Functional and structural aspects of the epithelial lymphocyte, with implications for coeliac disease and tropical sprue. Scand J Gastroenterol 20 [Suppl 114]: 55

71. Marsh MN (1987) Coeliac disease. In: Marsh MN (ed) Immunopathology of the small intestine. Wiley, Chichester, pp 371-399 
72. Marsh MN, Hinde J (1986) Morphometric analysis of small intestinal mucosa. III. The quantitation of crypt epithelial volumes and lymphoid cell infiltrates, with reference to celiac sprue mucosa. Virchows Arch [A] 409: 11

73. Mavromichalis J, Brueton MJ, McNeish AS, Anderson CR (1976) Evaluation of the intraepithelial lymphocyte count in the jejunum in childhood enteropathies. Gut 17: 600

74. Mayer L, Shlien R (1987) Evidence for function of Ia molecules on gut epithelial cells in man. J Exp Med 166: 1471

75. Mayrhofer G (1980) Thymus-dependent and thymus-independent subpopulations of intestinal intraepithelial lymphocytes: a granular subpopulation of probable bone marrow origin and relationship to mucosal mast cells. Blood 55: 532

76. Mayrhofer G, Whately RJ (1983) Granular intraepithelial lymphocytes of the rat small intestine. I. Isolation, presence in T lymphocyte-deficient rats and bone marrow origin. Int Arch Allergy Appl Immunol 71: 317

77. Meader RD, Landers DF (1967) Electron and light microscopic observations on relationships between lymphocytes and intestinal epithelium. Am J Anat 121: 763

78. McDermott MR, Horsewood P, Clark DA, Bienenstock J (1986) T lymphocytes in the intestinal epithelium and lamina propria of mice. Immunology 57: 213

79. Monk T, Spencer J, Cerf-Bensussan N, MacDonald TT (1988) Stimulation of mucosal T cells in situ with anti-CD3 antibody: location of the activated $T$ cells and their distribution within the mucosal microenvironment. Clin Exp Immunol 74: 216

80. Moretta A, Bottino C, Ciccone E, Tambussi G, Mingari MC, Ferrini S, Casorati G, Varese P, Viale O, Migone N, Moretta L (1988) Human peripheral blood lymphocytes bearing $T$ cell receptor $\gamma \delta$. Expression of CD8 differentiation antigen correlates with the expression of the 55-kD, C $\gamma 2$-encoded $\gamma$ chain. J Exp Med 168: 2349

81. Mowat AMcI, Felstein MV (1987) Experimental studies of immunologically mediated enteropathy. II. Role of natural killer cells in the intestinal phase of murine graft-versus-host reaction. Immunology 61: 179

82. Mowat AMcI, Felstein MV (1989) Intestinal graft-versus-host reactions in experimental animals. In: Burakoff SJ, Ferrara J (eds) Graft-versus-host disease. Dekker, New York (in press)

83. Mowat AMcI, Ferguson A (1981) Hypersensitivity reactions in the small intestine. VI. Pathogenesis of the graft-versus-host reaction in the small intestinal mucosa of the mouse. Transplantation 32: 238

84. Mowat AMcI, Ferguson A (1981) Hypersensitivity in the small intestinal mucosa. V. Induction of cell mediated immunity to a dietary antigen. Clin Exp Immunol 43: 574

85. Mowat AMcI, Ferguson A (1982) Intraepithelial lymphocyte count and crypt hyperplasia measure the mucosal component of the graft-versus-host reaction in mouse small intestine. Gastroenterology 83: 417

86. Mowat AMcI, Tait RC, MacKenzie S, Davies MDJ, Parrott DMV (1983) Analysis of natural killer effector and suppressor activity by intraepithelial lymphocytes from mouse small intestine. Clin Exp Immunol 52: 191

87. Mowat AMcI, Borland A, Tait RC, Parrott DMV (1984) NK cells and small intestinal immunity. In: Chadwick VS (ed) Mechanisms of gastrointestinal inflammation. SK \& F Publications, pp 5

88. Mowat AMcI, MacKenzie S, Baca ME, Felstein MV, Parrott DMV (1986) Functional characteristics of intraepithelial lymphocytes from mouse small intestine. II. In vivo and in vitro responses of intraepithelial lymphocytes to mitogenic and allogenic stimuli. Immunology 58: 627

89. Mowat AMcI, McInnes IB, Parrott DMV (1989) Functional properties of intraepithelial lymphocytes from mouse small intestine. IV. Investigation of the proliferative capacity of IEL using phorbol ester and calcium ionophore. Immunology 66: 398

90. Nauss KM, Pavlina TM, Kumar V, Newberne PM (1984) Functional characteristics of lymphocytes isolated from the rat large intestine. Gastroenterology 86: 468

91. Nizai NM, Leigh R, Crowe P, Marsh MN (1984) Morphometric analysis of small intestinal mucosa. I. Methodology, epithelial volume compartments and enumeration of interepithelial space lymphocytes. Virchows Arch [A] 404: 49

92. Otto HF (1973) The intraepithelial lymphocytes of the intestinum. Morphological observations and immunological aspects of intestinal enteropathy. Curr Top Pathol 57: 81

93. Owen RL, Nemanic PC, Stevens DP (1979) Ultrastructural observations on Giardiasis in a 
murine model. I. Intestinal distribution, attachment, and relationship to the immune system Giardia muris. Gastroenterology 76: 757

94. Parrott DMV, Tait C, MacKenzie S, Mowat AMcI, Davies MDJ, Micklem HS (1982) Analysis of the effector functions of different populations of mucosal lymphocytes. Ann NY Acad Sci 409: 307

95. Petit A, Ernst PB, Befus AD, Clark DA, Rosenthal KL, Ishizaka T, Bienenstock J (1985) Murine intestinal intraepithelial lymphocytes. I. Relationship of a novel Thy-1 ${ }^{-}, \mathrm{Ly}_{-} \mathbf{1}^{-}, \mathrm{Ly}_{-} \mathrm{2}^{+}$ granulated subpopulation to natural killer cells and mast cells. Eur J Immunol 15: 211

96. Phillips AD, Rice SJ, France NE, Walker-Smith JA (1979) Small intestinal intraepithelial lymphocyte levels in cow's milk protein intolerance. Gut 20: 509

97. Reynolds JD, Morris B (1983) The influence of gut function on lymphoid cell populations in the intestinal mucosa of lambs. Immunology 49: 501

98. Ropke C, Everett NM (1976) Kinetics of intraepithelial lymphocytes in the small intestine of thymus-deprived mice and antigen-deprived mice. Anat Rec 185: 101

99. Rosekrans PCM, Meijer CJLM, Cornelisse CJ, Wal AMvd, Lindeman J (1980) Use of morphometry and immunohistochemistry of small intestinal biopsy specimens in the diagnosis of food allergy. J Clin Pathol 33: 125

100. Salter DM, Krajewski AS, Dewar AE (1986) Immunophenotype analysis of malignant histiocytosis of the intestine. J Clin Pathol 39: 8

101. Schrader JW, Scollay R, Babbye F (1983) Intramucosal lymphocytes of the gut: Ly-2 and Thy-1 phenotype of the granulated cells and evidence for the presence of both $T$ cell and mast cell precursors. J Immunol 130: 558

102. Selby WS, Janossy G, Jewell DP (1981) Immunohistological characterisation of intraepithelial lymphocytes of the human gastrointestinal tract. Gut 22: 169

103. Selby WS, Janossy G, Bofill M, Jewell DP (1983) Lymphocyte subpopulations in the human small intestine. The findings in normal mucosa and in the mucosa of patients with adult coeliac disease. Clin Exp Immunol 52: 219

104. Shields JG, Parrott DMV (1985) Appearance of delayed-type hypersensitivity effector cells in murine gut mucosa. Immunology 54: 771

105. Spencer J, Dillon SB, Isaacson PG, MacDonald TT (1986) T cell subclasses in fetal human ileum. Clin Exp Immunol 65: 553

106. Spencer J, Cerf-Bensussan N, Brousse $N$ et al. (1988) Enteropathy associated $T$ cell lymphoma (malignant histiocytosis of the intestine) is recognised by a monoclonal antibody (HML-1) that defines a membrane molecule on human mucosal lymphocytes. Am J Pathol 132: 1

107. Spencer J, MacDonald TT, Diss TC, Walker-Smith JA, Ciclitira PJ, Isaacson PG (1989) Changes in intraepithelial lymphocyte subpopulations in coeliac disease and enteropathy associated $\mathrm{T}$ cell lymphoma (malignant histiocytosis of the intestine). Gut 30: 339

108. Sprent J (1976) Fate of H-2 activated T-lymphocytes in syngeneic Hosts. I. Fate in lymphoid tissues and intestines traced with $\left[{ }^{3} \mathrm{H}\right]$ thymidine, $\left[{ }^{125} \mathrm{I}\right]$ deoxyuridine and ${ }^{51}$ chromium. Cell Immunol 21: 278

109. Steiner G, Koning F, Elve A, Tschachler E, Yokoyama WM, Shevach EM, Stingl G, Coligan JE (1988) Characterization of $T$ cell receptors on resident murine dendritic epidermal $T$ cells. Eur J Immunol 18: 1323

110. Suttles J, Schwarting GA, Stout RD (1986) Flow cytometric analysis reveals the presence of asialo $\mathrm{G}_{\mathrm{Ml}}$ on the surface membrane of alloimmune cytotoxic T lymphocytes. J Immunol 136: 1586

111. Tagliabue A, Luini W, Soldateschi D, Boraschi D (1981) Natural killer activity of gut mocusal lymphoid cells in mice. Eur J Immunol 11: 919

112. Tagliabue A, Befus AD, Clark DA, Bienenstock J (1982) Characteristics of natural killer cells in the murine intestinal epithelium and lamina propria. J Exp Med 155: 1785

113. Toner PG, Carr KE, Wyburn GM (1971) The digestive system. In: An ultrastructural atlas and review. Butterworth Press, London

114. Viney JL, MacDonald TT, Kilshaw PJ (1989) T cell receptor expression in intraepithelial lymphocytes of normal and athymic mice. Immunology (in press)

115. Weber EH (1847) First description of I. E. lymphocytes. Archiv für Anatomie. Physiologie Wiss Med, $\mathrm{p} 402$

116. Wilson AD, Stokes CR, Bourne FJ (1986) Responses of intraepithelial lymphocytes to T-cell mitogens: a comparison between murine and porcine responses. Immunology 58: 621 
117. Wilson AD, Stokes CR, Bourne FJ (1986) Morphology and functional characteristics of isolated procine intraepithelial lymphocytes. Immunology 59: 109

118. Wolf-Heidegger G (1939) Zur Frage der Lymphocytenwanderung durch das Darmepithel. Z Mikrosk Anat Forsch (Leipz) 45: 90

119. Wright SG, Tomkins AM (1977) Quantification of the lymphocytic infiltrate in jejunal epithelium in giardiasis. Clin Exp Immunol 29: 408

120. Zeitz M, Quinn TC, Graeff AS, James SP (1988) Mucosal T cells provide helper function but do not proliferate when stimulated by specific antigen in lymphogranuloma venereum proctitis in nonhuman primates. Gastroenterology 94: 353

\section{Note Added in Proof}

Recent findings confirm that human IEL are virtually all conventinal $\alpha \beta$ TcR-expressing T cells. However, there is an increased number of $\gamma \delta \mathrm{T}$ cells in patients with coeliac disease. This abnormality is specific to coeliac disease and remains after the intestine returns to normal on a gluten-free diet. This suggests that an inherently high proportion of $\gamma \delta^{+}$IEL may predispose to coeliac disease. Parallel studies in mice also indicate that $\gamma \delta^{+}$and $\alpha \beta^{+}$IEL are distinct populations of T cells which respond differently to local antigen. 